\title{
A Review on Concept of Kupipakva Rasayana
}

\author{
Dr. Sahu Gajendra ${ }^{1}$, Dr. Parhate S. M. ${ }^{2}$, Dr. Karbhal K. S. ${ }^{3}$ \\ ${ }^{1}$ PG Scholar, ${ }^{2}$ Professor and HOD, ${ }^{3}$ Reader PG Scholar \\ Rasshastra and Bhaishajya kalpana, Govt. Ayurvedic College, \\ Raipur, Chhattisgarh, India
}

\section{ABSTRACT}

The formulations prepared by subjecting suddhaparada, suddhagandhaka and any of the other rasadravya to a specific heat in any selected glass bottle following the unique method of preparation mentioned in the books is called as kupipakwarasayana. Kupipakwarasayanakalpana have always been known for their absolute potency and smaller dosage. They are largely produced and marketed by pharmaceutical companies. These formulations have very wider range of therapeutic utility.

KEY WORDS: Parada, Kupipakwa rasayana, Rasadravya

\section{INTRODUCTION}

The preceptors of Indian rasa shastra were initially indulged very much in the achievement of a disease free and decay free body (deha veda) and the conversion of a lower metal to a higher metal i.e. a metal having higher economic value (loha veda) simultaneously, but later their attempts in the field of deva veda became dominant.

Acharyas found mercury and few other minerals are very useful. They observed that some toxic and harmful effects are likely to be produced in the body if such metals minerals used in Ashodhita form, hence to minimize or remove their toxic effects shodhana, marana, Amritikarana procedures should be done. Kupipakva method is developed mainly for gandhakajarana in which Sulphur is added with mercury in different proportions and bburns it with the help of fire in glass bottle (kupi). The aim was to produce strong bond structure between the molecules of mercury and the Sulphur.

\section{History of Kupipakvarasayana}

The knowledge of KupiPakvvaRasayana thus came to India by various Siddhas In 8th century A.D

9th century A.D. - Gandhakjarana for the first time mentioned in Rasa HridayaTantra, further developed as Kupipakvarasayana. ${ }^{1}$

13th century A.D. - Information of Rasa SindoorKalpana, a Kupipakvarasayana, is for the first time available as Udayabhaskara Rasa ${ }^{2}$ in Rasa Prakash Sudhakar (R.P.S. 3/10- 14) by Shri Yashodara Bhatta. He used Kupi and SiktaYantra in the preparation. He also described the method of preparation of Rasa karpura as the name of Ghansara Rasa. ${ }^{3}$

15th century A.D. - Shri AnantadevSoori mentions the same as Rasaparthiva Rasa in Rasa Chintamani.

16tht and 17th century A.D. RasakaumudievamRasakalpayoga and Ayurveda Prakash respectively mention Sindoornama Rasa (Sindoor like Rasa). ${ }^{4}$ In RasendraChintamani ${ }^{5}$ there is clear cut specific heating pattern named as Kramagni ( Mridu, Madhya and Tikshna Agni ) has mentioned.

19th century A.D. - Rasatarangini mentions range of Kupipakvarasayana like Rasasindoor, Rasapushpa, Rasakarpoora, Makardhwaja and Swarnavanga, etc. along with modification like use of sulphuric acid in preparation of Rasa karpoora.

> Swami Harisharanand Vaidya has described 258 kupipakwarasayana in his text Kupiakava Rasa NirmanaVigyana

Kupi - The term kupi indicates suitale glass bottle; pakwa means paka in agni; rasa terms stands for parada and ayana means sthana. ${ }^{6}$

Pakva - which mean 'coocked in' "cooked by" 
Rasayana - The one which destroys the smile symptoms \& signs also the senile diseases, other diseases $\&$ rejuvenates the person.

KupipakvaRasayana -The rasayana which is made by cooking over fire in a kupi is known as kupipakvarasayana.

\section{Classification}

Kupipakvakalpanas can be classified as follows-

1. According to ingredients :

A. Sagandha- Those which contain gandhaka as an ingredient. $^{7}$

1. Parada + Gandhak $\rightarrow$ RasSindura

2. Parada + Gandhaka + Dhatu $\rightarrow$ Naga sindura

3. Parada + Gandhaka + Adhatu $\rightarrow$ Mallasindura

4. Parada + Gandhaka + Adhatu + Swarna Poornachandrodaya rasa

B. Nirgandha- where gandhak is not used eg.Rasapuspa, Rasakarpura

2. According to manufacturing method :

A. Antardhuma - Cork is applied in the beginning, the fumes are not allowed to escape eg. Sameerpanaga rasa, Sarvangasundar rasa.

B. Bahirdhoomavidhi- Cork is applied after burning of sulphur. e.g. Rasa sindoora.

3. Depending upon the deposition site of finished product-

A. Galastha or Kantastha- Final product is accumulated at the neck of bottle eg. Rasa sindoora

B. Talastha or Adhastha - The product is obtained at the base of bottle eg. SameerapannagaRasa, Rasa Sindoora

C. Ubhayastha- Medicine accumulated both at neck and the base of the bottle. e.g. Poornachandrodaya, rasamanikya, etc.

\section{Procedure ( Method of Preparation):}

Kupipakva - rasayana procedure can divide into three phases:

1. Purva karma : It includes -

A. Kajjali Preparation and Trituration

B. Coating of bottle (Kapadmitti)

C. Filling of raw material in bottle.

2. Pradhan karma: It includes -

A. Heating procedure and temperature pattern.

B. Observations

C. Cleaning of mouth of bottle
D. Paka-pariksha

E. Precautions

F. Mudrana (Sealing) Procedure.

3. Paschatkarma: It includes -

A. Breaking of bottle

B. Test of prepared medicine

C. Storage

\section{Place for preparation of Kupipakva Rasayana:-}

$>$ The room in which the furnace (Bhatti) is to be bu ilt should be enough high $\&$ must have proper ven tilation i.e should have enough number of window s \& gate. So that the smoke \& heat of the furnace does not cause any trouble to the Worker/Maker o r Observer.

Furnance is not to be built in open space, otherwise rain in rainy season and scorching sunlight in summer will cause trouble during the preparation \& with winds flowing, the heat will not be provided sufficiently.

The room should be sufficient roomy or should ha ve sufficient place to store fire material like wood, coal etc \& extra bags of sand.

\section{Appropriate Materials \&Equipment's -}

1. Kupi

2. ValukaYantra

3. Bhrastri, Chulika

4. KhalvaYantra(mortar and pestle)

5. Shalaka(Shitashalaka\&Ushanashalaka)

6. Copper coin or plate

7. Cork or sealing material

\section{A. Kupi -}

The glass bottle which is most convenient and quite regularly selected for this purpose is the beer bottle of $650 \mathrm{ml}$. capacity. It will be lengthy round and firm based with elongated neck and usually umber colour. synonyms of kupi are Kupika, Siddha, girindika etc. ${ }^{8}$

\section{History of kupi :}

Vaidya Harisharnanda stated in his text Kupiakvarasayana that the use of kanchkupi began from 10 th century A.D. when the science of preparing glass began in India.. Kupis made up of iron, silver, mud, gold were in use. Rasendramangala has described shadguna (six time) Balijarana in mercury by the help of Loha-crucible. Harisharnanda Vaidya had stated that a kanchkupi should have thin bottom and should not have a very long neck as the fumes of sulphur would block the neck and break the 
kupi. Now a days green colour or Amber colour beer bottles are used in practice.

\section{Advantages of kanchkupi:}

A. The most important advantage of glass bottle is the rasas which prepared in glass bottle the get very beautiful and smooth, slippery surface. This is not possible in any another material bottle.

B. It does not break suddenly during preparation.

C. During whole process Vapours do not escape out.

D. Breaking of glass bottle to collect the medicinr is also very easy \& convenient.

\section{Kapadamitti:}

Overlapping of kupi by the paste of Mritika (multani, khadiya or china clay) and cotton cloth are termed as Kapadmitti.

Aim: To enhance the heat tolerance capacity of Kupi and also to strengthen the glass bottle

$>$ Rasaratnasamucchaya describes the method of coating of Kupi with clay and cloth in detail. (R.R.S. 9/33-35). ${ }^{9}$

$>$ The bottle should be placed upside down in a rod stand keep a thin layer of clay at the bottom of Kupi and then a single piece of cotton strip, smeared with clay, should be placed downward from its bottom.

$>$ The cloth piece/the strip should be lengthy enough to cover both sides upto bottles mouth.

$>$ After proper drying of the first layer, should be put second layer. Another cotton strip smeared with clay should be placed in cross direction to previous strip from the bottom to the mouth of the bottle.

$>$ After coating it should be Press by hand to made it plane, smooth and so also to make sure that no free space or air bubble is present in between the bottle and strips, then it should be dried in sun.

$>$ Likewise, the texts of rasashastras describe total sevenlayers of coating of clay and cloth on kachakapi to make it strong and heat resistant.

$>$ Ayurveda Prakash ${ }^{10}$ describes saindhava and Ayaskriti and coating Khadiya clay (Ayu. Pra.1/194) whereas in RasendraChintamani, Khatika, Mud and Saindhava are described for coating on glass bottle (R.C.2/18).

\section{Balukayantra -}

This is the main requisite of kupipakvarasayana.Balukayantra consist of silica and earthen pot. A strong elongated bottle the mouth of which is constricted a little is taken and covered 7 layers of a cloth well soaked in homogenous paste of Multanimitti on it.

\section{Baluka-}

The Blukayantra should have capacity to accommodate 5 aadhaka of sand . Acharya Sadanand Sharma has mentioned that the sand should be fill up to the neck of the Kupi. ${ }^{11}$

\section{History OfValukayantra}

The usage of this yantra seem to be started from $9^{\text {th }}$ century

Rasratnasamucchya:A bhanda of 1 Vitasti filled with 5 adhaka of sand is taken for valukayantra, in which a Kachkupiwraped with 1 angula thick kapadmitti filled with 3 parts of it with kajjali,Thebhanda is then covered with another sharava\&sandhibandhana is done. $^{12}$

RasendraChintamani ${ }^{13}$ 2/7: The centre of the base of bhanda should have the hole of Tarjinianguli, which is closed with Abhrakapatra while filling it.It is then subjected to Kramagni of 3,4,5 days.

Rasendrachudamani ${ }^{14}$ Vessel contain 5 adhaka sand.

Rasa Tarangani 4/29-30 : Depth of Handi is mentioned as 12 Angulas, along with the indication of kapadmitti over handi too, before subjecting it to agni.

Acharya Yadavji : Acharya Yadav ji has mentioned the depth of vessel as 1 Vasthi.

Shalaka - The shalaka or Iron rod is usually used which is preferred to have more length or height than of kupi. The material of Shalaka should be inert in nature.

ShitaShalaka: Particles of ingredients are seen on the rod at the stage of melting of Kajjali.Some particles of the drug will stick on the shalaka which shows completion of paka.

TaptaShalaka:Material present at the mouth of the Kupi burns with a blue flame on insertion.It is used for removing extra Sulphur deposited at the neck region of kupi.

Preparation of kajjali- The purified parada and Gandhak are taken in clean khalvayantra and 
triturated continuously until appropriate kajjali is obtained.

Bhavana to kajjali- A powder of metal, minerals or any other substance is triturated with liquid substance till all the liquid is absorbed is known as Bhavna.

\section{Filling of Kajjali into Kupi -}

Only $1 / 4^{\text {th }}$ to $1 / 3^{\text {rd }}$ of the bottle is filled with kajjali and the remaining part is left vacant to allow better compound formation.

\section{Pradhan Karma-}

Before going to start the Pradhan karma some precautions should be taken, they are-

$>$ The mouth of the bottle should be covered temporarily with the cork and placed firmly in valukayantra pouring the sand into Valukayantra.

$>$ Kupi should be placed at the centre and with two inch thick sand at the base and sand upto neck in the surrounding.

\section{Temperature measurement:}

It is very much mandatory to control heat in kupipakva rasa preparation, to prepare proper medicine. Every Rasa-vaidya must know the temperature pattern and heat regulation.

\section{Heating Pattern:}

Heating pattern should always follow Kramavriddgni i.e. gradual increase in temperature.

\section{First stage- Mrudu Agni (125 - 250)}

Stage of liquefaction of ofKajjali. This is the stage where kajjali starts melting and Sulphur fumes are emitted .This is tested with the help of ShitaShalaka. The temperature of this stage ranges uto $250^{\circ} \mathrm{C}$. This heat is maintained for the prescribed time as to allow chemical reactions to begin

\section{Middle stage - Madhyamagni (250 -450)}

Stage of profuse fuming and boiling of kajjali

1. The kajjali starts to boil as a result of which fumes emerge gradually followed by flames.

2. When the neck of the bottle gets blocked it has to be frequently cleared carefully inserting the hot iron rod ( taptashalaka) selected for the purose.

3. Both fumes and flames subside at one point.

4. If the base of the bottle is visualized at this stage in torch light by keeping the surrouding dark, it appears deep red.
5. The new compound formation is anticipated at this stage.

\section{Third stage - Tivragni (450- 650)}

This stage commences from the formation of Sindura compound and lasts upto the completion of jarana of Gandhaka. As heating persist, this newly formed compound sublimates and gets condensed at the neck and mouth of the kupi.

1. At the end of middle stage Sulphur fumes catches fire and it takes a form of flame. In this end stage flame appears.

2. When extra sulphur burns out completely flame disappears and this indicates the completion of GandhakaJarana.

3. Redness starts appearing at the bottom of the Kupi, which gets more brightened ( Sooryodayalaxana). Sindura test becomes positive.

\section{Shalakasanchalana}

During the preparation sheet \& Tata Salakas are being in use.

Shitashalaka- It is used especially for noting the state of Kajjali, whether it is in powder form, melted state, in boiling state, or in sublimating compound state.

Taptashalaka - It is used for burning the sulphur accumulated at the neck region of Kupi.

\section{Observations of Fumes \&Flame:}

Fumes - All the features of fumes like colour, smell etc. should be observed. It differs according to the ingredients. Colour may be yellow, orange, quantity may be less, moderate, profuse, smell like sulphur odour, other odour may be some of the observations.

Flames - It is also an important factor while preparing kupiPakwaRasayanas. Its colour and its duration are the important features. These features also depend on the ingredients used.

\section{Copper coin or copper foils -}

To test that whether these are Fumes of Mercury, copper foil should be kept on the mouth of bottle. After removing if white coloured spot will be there on that copper Foil, it confirms that now the mercury is evaporating. It is a right time to apply mudrana (Sealing of the mouth of bottle) by the cork and clay 


\section{Mukhamudrana (corking of kupi)}

The closure of bottle opening with a cork is called as kupimukhamudrana or mudra. The cork is usually prepared by rolling the wet mud smeared cloth tightly into a small cork shape. It should be thicker at the top and comparatively narrower below. The narrower end is inserted into the Bottle mouth and fixed. The mudra preparation is also called other names like hata mudra and madana mudra.

\section{Importance of cork-}

$>$ To avoid loss of finished product.

$>$ To obtain kanthastharasayanas

$>$ To avoid entrance of foreign material

\section{Swangasheetikarana (self cooling)}

After corking bhrastri is left for self cooling to assist condensation of the formed sindura compound in the neck portion of the kupi. It enhances the quality of sindura by its complete pachanpaka process.

\section{PaschatKarms -}

It is considered as Paschat karma or it can also be called as final step. The bottle in which medicine is prepared has to be broken with all care and gentleness so that the drug inside is completely collected without any loss. It includes the following.

Removal of Kupi- First sand should be removed from balukayantra after that Kupi is taken out with care (sometimes it may be possible that Kupi is broken inside but remain intact due to layers of cloth).

Scraping of outer coverings- layers of cloth smeared with mud is removed and kupi should be cleaned with wet cloth, then mark the level of Rasayana inside the neck / bottom.

\section{Breaking of Kupi ${ }^{16}$}

1. A jute thread soaked in kerosene is tied around the bottle where it needs to be broken. The thread is ignited allowed to burn fully.

2. After the thread is burnt its remaining part if any on the bottle is removed and soon the bottle is horizontally rolled in a wet cloth spread on an even surface.

3. Here the part of the bottle hot because of the thread bulge.As a result of sudden change in temperature the glass breaks precisely at the areas it is intended to and while breaking a clear sound of the same is heared cloth; the two broken parts of the bottle are cautiously collected held inverted and gently stroked to collect the medicine adherent inside in the same shape.

Collection of product- Kupipakwarasayana product which may be kantastha or Talastha type, should be collected carefully from the particular portion Then the product is analyzed to classical and modern techniques.

Sindurabhasmapariksha- When the sindurabhasma is subjected to flame test, there should not be any emission of fumes, discolouration or odour.The genuine bhasma is guru so that it sinks into water when spread as a thin layer over it.

\section{Discussion}

The introduction of the Kupipakwarasayana was proven revolutionary in field of Rasashasra for clinical practice. Rasa sindura, Makaradhwaj, Rasa karpura, Swarnavanga as well as base of many rasaushadhies. Later on after $8^{\text {th }}$ century in the rasa grant ou has like Rasaratnasamucchaya, Rasendrachintamani, Rasatarangani a through description of the Valukayantra \& kachkupi to be used and agni to be given was mentioned which proves the refining of this process with time.Granthas like Kupipawarasayana by Harisharnananda Vaidya were full of the minor details of the whole kupipakwa process.

\section{Conclusion}

A kind of metallic preparations which is commonly prescribed by ayurvedic physician known as KupipakwaRasayana. It has disease curing properties due to paradamurchana. Sometimes many chemical reactions are involved to give synergistic effect in the body. By this different minerals and metals are transformed into effective medicines. The actions of Kupipakwarasayana remain for longer period of time which indicates its greater potency and efficacy. It is very effective even at minimum dose with ease of administration. When kupipakwa medicines are mixed with other medicines, it minimizes the dose of other medicines. ${ }^{17}$ When it is compared with other Rasaushadhi like Kajjali, Parpati, Pottali its chemical bonding are stronger among these three. It is more potent than any of other herbal preparations. 
International Journal of Trend in Scientific Research and Development (IJTSRD) ISSN: 2456-6470

References-

1. Mishra Chaturbhuja, Rasa Hridayatantra, Krishnagopalayurvedbhavankaledafirst edition 1958. Chaper-5/11, pp- 103.

2. MishraS.N., Rasa PrakashaSudhakara, ChoukhambaOrientaliaVaranasi, Reprint 2013, Chapter-3/10-14, page no.53-54.

3. Acharya bhataYashodhar, RasaprakashaSudhakara Translated by Siddhinandana Mishra, Edition $2{ }^{\text {nd }}$ Varanasi, ChaukambaOrientalia $3^{\text {rd }}$ chapter version $6^{\text {th }}-14^{\text {th }}$ ,53pp.

4. Sharma Gulraj, Ayurved Prakash, chaukhambhavidyabhavan Varanasi, second edition samvat 2019, Chapter 1/399-400,pp-196.

5. Mishra

S.N.

RasendraChintamani, ChauukhambaOrientalia Varanasi, Reorint 2006, Chapter 2/8-9, pp-12-13.

6. Jha C.B. Ayurvediya Rasa Shastra, ChaukhambaSurbharatiPrakashanVaranasi Reprint edition 2007, pp-173

7. JhaC. B. Ayurvediya Rasa Shastra, ChaukhambaSurbharatiPrakashanVaranasi, Reprint edition 2007, pp-173-174.

8. Sharma Gulraj, Ayurved Prakash , chaukhambhavidyabhavan Varanasi, second edition samvat 2019, chapter 1/94, pp-107
9. Kulkarni Dattatreya, RasRatnaSamucchya, Meharchandlaxman das publications, Third edition 1982, chapter 9/33-35, pp-170

10. Sharma Gulraj, Ayurved Prakash , chaukhambhavidyabhavan Varanasi, second edition samvat 2019, Chapter 1/194, pp-107

11. ShastriKashinatha , Rasa Tarangini, Motilalbanarsi das publication delhi, chapter 4/29-30, $11^{\text {th }}$ edition 2009.pp-52

12. Kulkarni Dattatreya, RasRatnaSamucchya, Meharchandlaxman das publications, Third edition 1982, chapter 9/36-39, pp-170

13. Mishra S.N. RasendraChintamani, ChauukhambaOrientalia Varanasi, Reprint 2006, Chapter 2/7, pp-170

14. VajpeyiRameshverDayal, RasendraChudamani, Krishna das academy Varanasi, first edition 2004. Pp- 63.

15. ShastriKashinatha Rasa Tarangini, Motilalbanarsi das publication delhi, chapter $4 / 29-30,11^{\text {th }}$ edition 2009.pp-52

16. AngadiRavindra, A text book of Rasa Shastra, ChaukhambaSurbharatiPrakashan, first edition 2014, pp- 170

17. Mishra Ashisha at all, A Descriptive overview on kupipakwarasayana, Indian journal of agriculture and allied sciences, ISSN 2395-1109; Volume: 1, No.: 4, Year: 2015 